\title{
Effect of vitamin D supplementation on bone health parameters of healthy young Indian women
}

\author{
Nidhi Malhotra $\cdot$ Ambrish Mithal $\cdot$ Sushil Gupta $\cdot$ \\ Manoj Shukla • Madan Godbole
}

Received: 22 February 2009 / Accepted: 8 June 2009 / Published online: 14 July 2009

(C) The Author(s) 2009. This article is published with open access at Springerlink.com

\begin{abstract}
Summary There is a huge prevalence of hypovitaminosis D in the Indian population. We studied the efficacy and safety of oral vitamin D supplementation in apparently healthy adult women. Monthly cholecalciferol given orally, $60,000 \mathrm{IU} /$ month during summers and 120,000 IU/month during winters, safely increases 25 -hydroxyvitamin D (25 $(\mathrm{OH}) \mathrm{D})$ levels to near normal levels.

Introduction There is a huge burden of hypovitaminosis $\mathrm{D}$ in the Indian population. The current recommendation for vitamin D supplementation is not supported by sufficient evidence.

Methods Study subjects included 100 healthy adult women of reproductive age group from hospital staff. They were randomized into group A (control) and group B (supplement) by simple randomization. Group $B$ received $60,000 \mathrm{IU}$ of cholecalciferol/month administered orally for 3 months, and then group A received 60,000 IU and group B 120,000 IU/month for 6 months.

Results Mean baseline 25(OH)D level was $4.5 \pm 3.1 \mathrm{ng} / \mathrm{ml}$ and parathyroid hormone level was $50 \pm 25 \mathrm{pg} / \mathrm{ml}$. In group B, 25(OH)D levels increased from $4.8 \pm 3.5$ to $31.6 \pm 15.5 \mathrm{ng} / \mathrm{ml}$ $(P<0.001)$ in 3 months. Interestingly, the increase, although of lower magnitude, was also observed in control group A, from $4.5 \pm 3.4 \mathrm{ng} / \mathrm{ml}$ (in spring) to $10.8 \pm 7.2 \mathrm{ng} / \mathrm{ml}$ (in summer; $P<0.001)$. In group A $(60,000 \mathrm{IU} /$ month $)$, mean 25 $(\mathrm{OH}) \mathrm{D}$ level had increased to $22.3 \pm 12.4 \mathrm{ng} / \mathrm{ml}(P<0.001)$ at 9 months (winter). In group B $(120,000 \mathrm{IU} /$ month), $25(\mathrm{OH})$
\end{abstract}

N. Malhotra $(\bowtie) \cdot$ A. Mithal

Indraprastha Apollo Hospital,

New Delhi, India

e-mail: docnidhi1@rediffmail.com

S. Gupta $\cdot$ M. Shukla $\cdot$ M. Godbole

Sanjay Gandhi Postgraduate Institute of Medical Sciences,

Lucknow, India
D levels were maintained at $30.7 \pm 12.8 \mathrm{ng} / \mathrm{ml}$ at 9 months (winter).

Conclusion Our data show that monthly administration of 60,000 IU cholecalciferol in healthy subjects with hypovitaminosis D may suffice in summer months, but higher doses may be more appropriate during winter months.

Keywords Hypovitaminosis D · Cholecalciferol · 25(OH)D

\section{Introduction}

Vitamin D is widespread in nature and photosynthesized in most plants and animals exposed to sunlight [1]. Its major role in vertebrate animals and humans is to increase the absorption of calcium and phosphate for mineralization of the skeleton. In vitamin D-deficient children, the cartilage is not calcified, causing rickets. In adults with vitamin $\mathrm{D}$ deficiency, the newly formed bone matrix (the osteoid) is not mineralized, causing osteomalacia [2].

Synthesis of vitamin D takes place in the skin under the effect of sunlight. The Indian subcontinent is situated between $8.4^{\circ} \mathrm{N}$ and $37.6^{\circ} \mathrm{N}$ latitude and has adequate sunshine throughout the year. Despite this fact, studies have shown widespread prevalence of hypovitaminosis D that may have an adverse impact on bone health [3-7]. Even frank nutritional osteomalacia has been reported in urban Indians [8]. Avoidance of sunlight, cultural and clothing practices, and skin pigment are factors contributing to vitamin D deficiency. Increasing urbanization that results in poor outdoor activity and greater pollution may further aggravate the problem [9].

Severe vitamin D deficiency results in clinically apparent metabolic bone disease, i.e., rickets and osteomalacia. Subclinical vitamin D deficiency or insufficiency can result 
in decrease in overall bone mass and, therefore, an increased risk of osteoporosis [3, 10]. Adequate replacement with vitamin $\mathrm{D}$ can increase the bone mass and decrease the risk of fractures [11].

The optimal dose of vitamin D intake for the general population remains a subject of controversy. Experts now feel that 25-hydroxyvitamin D (25(OH)D) level of $30 \mathrm{ng} / \mathrm{ml}$ is required for maintaining optimal skeletal health [12]. Average 25(OH)D levels in Indians have been reported to be between 3 and $10 \mathrm{ng} / \mathrm{ml}$ in various studies especially from north India. The recommended doses of vitamin D (200-400 IU/day) intake are grossly inadequate to bring such low 25(OH)D levels to the desired levels [13-17]. This study was, therefore, undertaken to assess the efficacy and safety of cholecalciferol supplementation administered orally, 60,000 and $120,000 \mathrm{IU} /$ month equivalent to $2,000 \mathrm{IU} /$ day $(50 \mu \mathrm{g} /$ day $)$ and 4,000 IU/day $(100 \mu \mathrm{g} /$ day $)$, respectively, in apparently healthy Indian women. This dose was chosen because this preparation is commonly and widely used in Indian setting, and the dose seems to be in agreement with the current suggestions available on vitamin D supplementation in the literature [14]. According to present studies, a dose as high as 10,000 IU/day is likely to pose no risk of adverse effects [18].

\section{Methods}

\section{Subjects}

Study subjects included 100 apparently healthy adult Indian women of reproductive age group. They were all employees of Indraprastha Apollo Hospital (nurses, doctors, and administrative staff) who volunteered to participate in the study. None of these subjects had clinical signs and symptoms of overt metabolic bone disease such as bone pains, myopathy, or fractures. Study subjects included menstruating women $>18$ years of age.

Exclusion criteria included history of renal failure, liver failure, malabsorption disorder, known disorders of parathyroid function, hypercalcemia, hypocalcemia, known history of vitamin $\mathrm{D}$ intoxication and granulomatous diseases, and history of drug ingestion known to affect vitamin D metabolism (steroids, phenytoin, carbamazepine, and rifampicin).

Daily intake of dietary calcium was calculated from a food frequency questionnaire. Sunlight exposure was assessed by taking history of duration of daily sunlight exposure.

Study design and conduct

Study subjects were randomized into two groups: group A and group B by simple randomization. They were randomly assigned to receive either vitamin D supplementation with cholecalciferol $60,000 \mathrm{IU} /$ month administered orally or no supplementation in a 1:1 ratio, during the month of March (spring). This randomization was done regardless of their baseline 25(OH)D status. Group B received one sachet of cholecalciferol (containing 1,500 $\mu \mathrm{g} / 60,000 \mathrm{IU}$ vitamin $\mathrm{D}_{3}$, Cadila Pharmaceutical, India) per month, dissolved in a glass of milk, for 3 months. Subjects were made to drink this milk once a month under observation (Fig. 1).

The baseline results showed presence of hypovitaminosis $\mathrm{D}$ in all the study subjects $(25(\mathrm{OH}) \mathrm{D}<20 \mathrm{ng} / \mathrm{ml})$. At 3 months of review by the ethics committee, it was suggested that the study design be modified since it would be unethical to keep the subjects in group A, with significant hypovitaminosis $\mathrm{D}$, deprived of vitamin D. In view of this, after 3 months, group A (low-dose group) received one sachet of cholecalciferol $(60,000 \mathrm{IU})$ and group B (high-dose group) received two sachets of cholecalciferol $(120,000 \mathrm{IU})$ once a month for 6 months. Vitamin D doses are usually described in their daily amounts; we, therefore, express the monthly doses given here in their average daily amounts of 2,000 IU/day $(50 \mu \mathrm{g} /$ day $)$ and 4,000 IU/day $(100 \mu \mathrm{g} /$ day $)$. Blood and urine samples were drawn at 3 months (June, summer) and again at 9 months (December, winter).

Daily dietary intake of calcium was measured by semiquantitative food frequency questionnaire. All subjects were given diet charts that provided $800-1,000 \mathrm{mg}$ of calcium/day. The study protocol including vitamin D supplementation was approved by the ethics committee of our institution, and informed consent was obtained from all the subjects.

Follow-up, compliance, and actual number of subjects analyzed

At baseline, there were 100 subjects $(\mathrm{A}-50, \mathrm{~B}-50)$. Nine subjects lost follow-up at 3 months (A-42, B-49), and 31 subjects lost follow-up at 9 months (A-32, B-37). The reason for drop out was migration.

\section{Biochemical estimations}

Blood samples were drawn after an overnight fast between 0800 and 1000 hours at 0,3 , and 9 months for calcium, phosphorus, alkaline phosphatase, $25(\mathrm{OH}) \mathrm{D}$, parathyroid hormone (PTH) estimation, and urine samples for calcium, phosphorus, and creatinine estimation. Samples for 25(OH)D and intact PTH were cold-centrifuged for $15 \mathrm{~min}$ at $8^{\circ} \mathrm{C}$, and serum was stored in plastic aliquots at $-20^{\circ} \mathrm{C}$. The frozen serum was then transported on dry ice to Sanjay Gandhi Post Graduate Institute, Lucknow, India. Serum 25(OH)D concentrations were estimated by radioimmunoassay (Diasorin, Stillwater, MN 55082-0285, USA; kit, normal range 9.3$37.9 \mathrm{ng} / \mathrm{ml})$. The sensitivity of this assay is $1.5 \mathrm{ng} / \mathrm{ml}$, within- 
Fig. 1 Study design

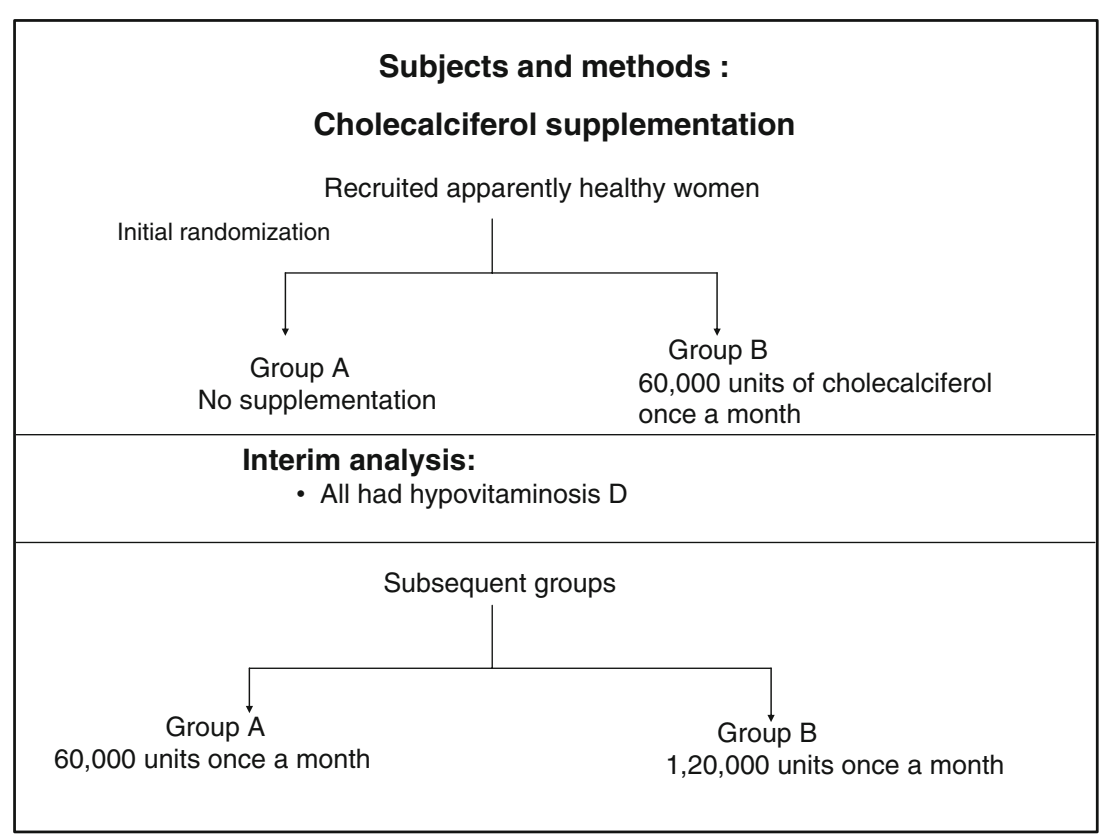

run coefficient of variation (CV) is $10.5 \%$, and the total imprecision $\mathrm{CV}$ is $8.2 \%$ at $22.7 \mathrm{ng} / \mathrm{ml}$. Vitamin D deficiency, insufficiency, and sufficiency were defined based on serum 25 $(\mathrm{OH}) \mathrm{D}$ concentrations as $<20,20-30$, and $>30 \mathrm{ng} / \mathrm{ml}$, respectively [13-15]. The assays were analyzed in duplicate. Serum intact PTH was measured by using an immunoradiometric assay (Diasorin; 10-55 pg/ml). However, 10-55 pg/ml is the locally determined PTH range used at SGPGI Laboratory, which has been analyzing these tests for several years. Analytical sensitivity of the assay is $0.7 \mathrm{pg} / \mathrm{ml}$. Intraassay variation is $3.6 \%$ at mean value of $26 \mathrm{pg} / \mathrm{ml}$, and interassay variation is $3.4 \%$ at mean value of $49 \mathrm{pg} / \mathrm{ml}$. Serum total calcium, inorganic phosphorus, and alkaline phosphatase were estimated by colorimetric method using commercial kits.

\section{Statistical analysis}

Results are expressed as means \pm SDs. Analysis was performed using SPSS software (version 12.0). Group means were compared by using parametric (paired $t$ test). Nonparametric test (Wilcoxon-signed ranks test) was used to compare various indices at three different time intervals because the variables did not show normal distribution. A $P$ value of $<0.05$ was considered significant.

\section{Results}

Baseline characteristics

One hundred healthy volunteers were recruited during the spring month of March 2007. Mean age and body mass index of the females was $26.82 \pm 5.14$ years and $22.34 \pm$
$3.61 \mathrm{~kg} / \mathrm{m}^{2}$, respectively. Mean dietary calcium intake was $525 \pm 176.53 \mathrm{mg} /$ day. Range for daily calcium intake estimate was 200-1,200 mg/day. Mean daily sunlight exposure was $15 \pm 5 \mathrm{~min} /$ day. The average body surface area exposed during winters was $10 \%$ and during summers $20 \%$. None of the study subjects had any signs and symptoms of vitamin $\mathrm{D}$ deficiency.

Mean 25(OH)D was $4.7 \pm 3.4 \mathrm{ng} / \mathrm{ml}$ and PTH was $50 \pm$ $24 \mathrm{pg} / \mathrm{ml}$. All our subjects had hypovitaminosis D (<20 ng/ $\mathrm{ml})$. Ninety-four percent of the subjects in group A and $90.6 \%$ of the subjects in group B had $25(\mathrm{OH}) \mathrm{D}$ levels $<10 \mathrm{ng} / \mathrm{ml}$. There were no between-group differences in age, calcium intake, sunlight exposure, and baseline biochemical bone parameters (Table 1).

At 3 months follow-up

Blood and urine samples were drawn after 3 months, during the month of June (summer). In group B (high-dose group), serum 25(OH)D levels increased from $4.8 \pm 3.5 \mathrm{ng} / \mathrm{ml}$ (March) to $31.6 \pm 15.5 \mathrm{ng} / \mathrm{ml}$ (June), after 3 months of supplementation with 60,000 IU of cholecalciferol per month administered orally $(P<0.001$; Fig. 2a). This statistically significant increase had brought down the percentage of subjects with $25(\mathrm{OH}) \mathrm{D}<20 \mathrm{ng} / \mathrm{ml}$ from $100 \%$ at baseline to $30 \%$ after supplementation, and only four subjects $(8.2 \%)$ had $25(\mathrm{OH}) \mathrm{D}<10 \mathrm{ng} / \mathrm{ml}$. The associated decrease in serum intact PTH and serum total alkaline phosphatase level was also significant $(P<0.05)$.

In group A (low-dose group), increase in serum $25(\mathrm{OH})$ D levels was also observed, from $4.5 \pm 3.4$ (March) to $10.8 \pm$ $7.2 \mathrm{ng} / \mathrm{ml}$ (June; $P<0.001$ ). This increase was found to be significant $(P<0.001)$ but was markedly less as compared 
Table 1 Comparison of baseline parameters between group A and group B

\begin{tabular}{lcc}
\hline Variable & Group A (control), $N=50$ (mean $\pm \mathrm{SD})$ & Group B (supplement), $N=50(\mathrm{mean} \pm \mathrm{SD})$ \\
\hline Age (years) & $26 \pm 6.32$ & $27 \pm 6.16$ \\
Serum calcium (mg/dl) & $9.06 \pm 0.40$ & $9.10 \pm 0.38$ \\
Serum phosphorus (mg/dl) & $3.84 \pm 0.55$ & $4.0 \pm 0.60$ \\
Serum alkaline phosphatase (IU/l) & $75 \pm 24$ & $69 \pm 22$ \\
Serum creatinine (mg/dl) & $0.67 \pm 0.11$ & $0.68 \pm 0.11$ \\
25(OH)D (ng/ml) & $4.5 \pm 3.4$ & $4.8 \pm 3.5$ \\
PTH $(\mathrm{pg} / \mathrm{ml})$ & $52 \pm 25$ & $49 \pm 24$ \\
\hline
\end{tabular}

Between-group differences were not significant, $P>0.05$

to that in group B (Fig. 2a). Ninety percent of the subjects in group A continued to have $25(\mathrm{OH}) \mathrm{D}<20 \mathrm{ng} / \mathrm{ml}$. Interestingly, significant decrease in serum intact PTH and serum total alkaline phosphatase level was also observed. There was no significant change observed in other biochemical variables.
After 6 months of supplementation (December)

At the end of 3 months, group A received $60,000 \mathrm{IU}$ and group B received 120,000 IU of cholecalciferol once a month administered orally for 6 months. Samples were a
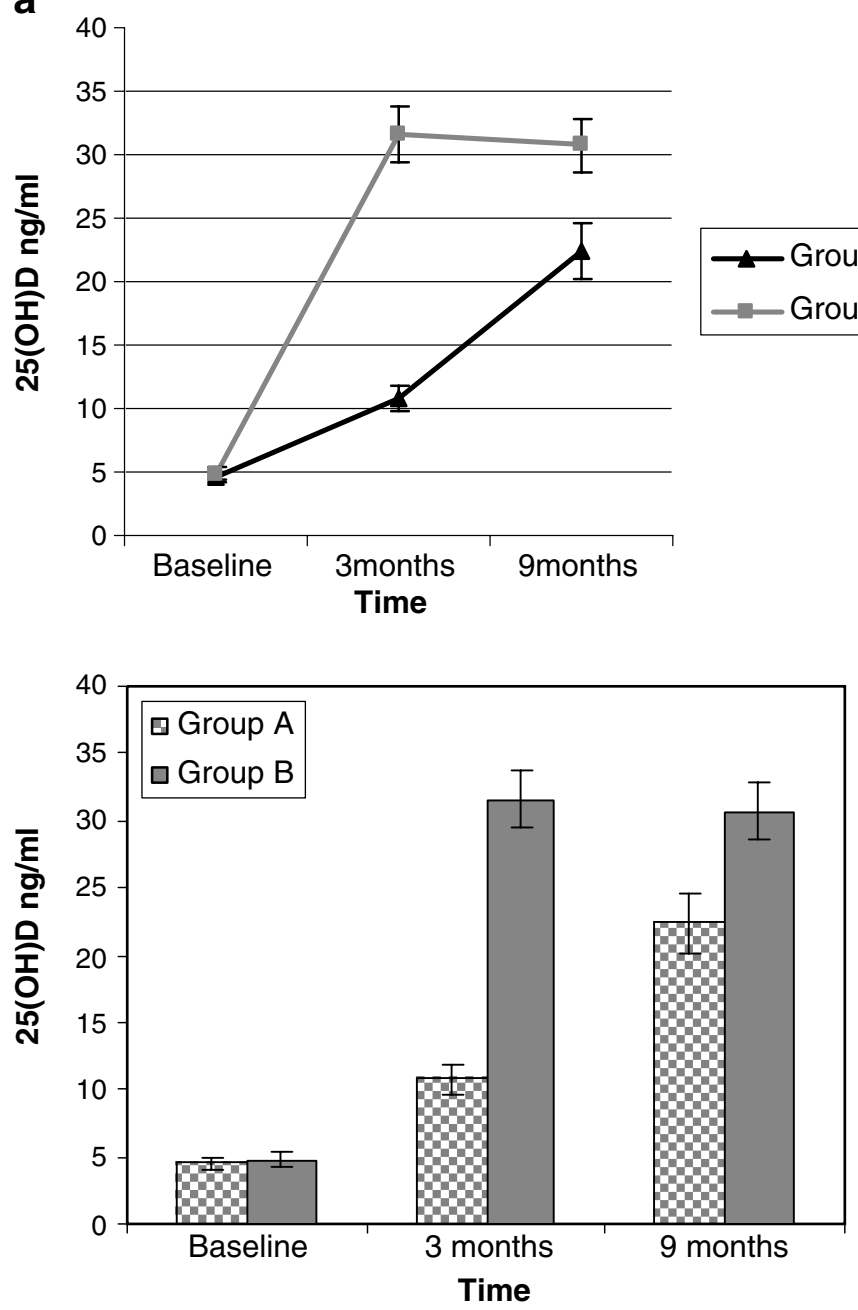

b
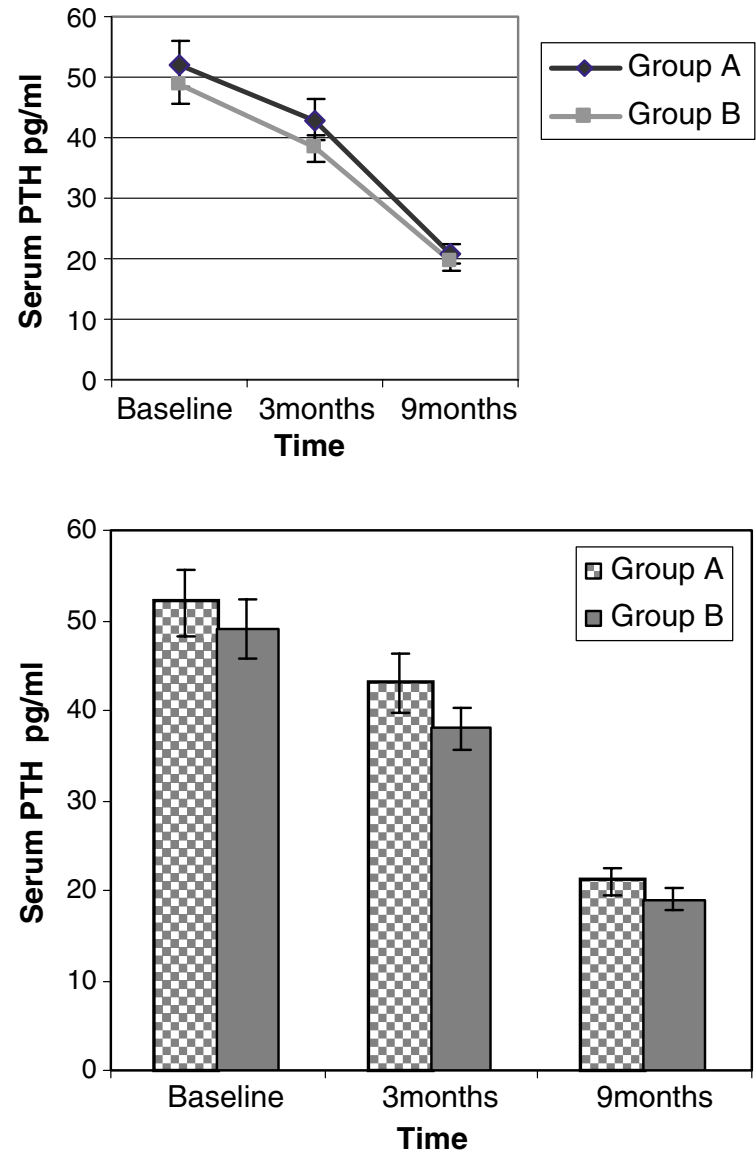

Fig. 2 a Change in $25(\mathrm{OH}) \mathrm{D}$ levels in groups A and B. b Change in PTH levels in groups A and B 
drawn after 6 months during the month of December (winters).

In group A, 25(OH)D levels increased from $10.8 \pm 7.2$ to $22.4 \pm 12.4 \mathrm{ng} / \mathrm{ml}(P<0.001)$ in 6 months (Fig. 2a). Serum PTH levels declined from $43 \pm 22$ to $21 \pm 9 \mathrm{pg} / \mathrm{ml}(P<0.001$; Fig. 2b), and serum calcium levels had increased $(P=$ 0.001). Change in other biochemical parameters was not found to be significant. Fifty-five percent of the subjects in group A had 25(OH)D $>20 \mathrm{ng} / \mathrm{ml}$ and $9.7 \%$ of the subjects had $25(\mathrm{OH}) \mathrm{D}<10 \mathrm{ng} / \mathrm{ml}$ after 6 months of supplementation with 60,000 IU of cholecalciferol once a month (Fig. 3).

In group $\mathrm{B}, 25(\mathrm{OH}) \mathrm{D}$ levels did not change after 6 months of supplementation with 120,000 IU of cholecalciferol once a month. Mean 25(OH)D level at 3 months was $31.6 \pm 15.5 \mathrm{ng} / \mathrm{ml}$ and, at 9 months, was $30.7 \pm 12.8 \mathrm{ng} / \mathrm{ml}$ (Fig. 2a). However, the percentage of subjects with $25(\mathrm{OH})$ D $>20 \mathrm{ng} / \mathrm{ml}$ had increased to $82 \%$ and only one subject (2.7\%) had 25(OH)D $<10 \mathrm{ng} / \mathrm{ml}$ (Fig. 3). Serum PTH levels reduced from $38 \pm 16$ to $19 \pm 8 \mathrm{pg} / \mathrm{ml}(P<0.001$; Fig. $2 \mathrm{~b})$. Increase in serum calcium was found to be significant in both groups $(P<0.05)$, although it did not exceed the upper limit of normal in any subject.

\section{Discussion}

The current study evaluates serum 25(OH)D and PTH responses at 3 and 9 months after oral supplementation with cholecalciferol once a month in apparently healthy adult women of reproductive age group. Our data confirm high prevalence of vitamin D deficiency in India, as shown in previous studies [3-7]. This is despite the fact that India is a tropical country with abundant sunshine. The increasing awareness about widespread prevalence of vitamin D deficiency has led to an ongoing debate regarding corrective measures and adequate intake to correct hypovitaminosis D. Based on currently available evidence, serum 25 $(\mathrm{OH}) \mathrm{D}$ level of $30 \mathrm{ng} / \mathrm{ml}$ provides several specific health benefits like optimal bone mineral density, improved

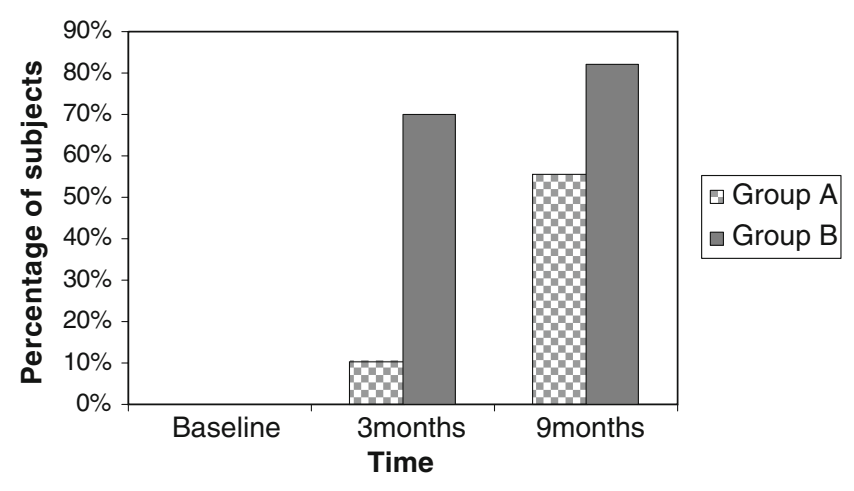

Fig. 3 Percentage of subjects with $25(\mathrm{OH}) \mathrm{D}>20 \mathrm{ng} / \mathrm{ml}$ muscle strength, and reduced risk of fall and fractures [12]. The recommended daily intake of vitamin $\mathrm{D}$ has been close to $10 \mu \mathrm{g}$ (400 IU/day) until 1997 [17]. Various studies have shown that this daily allowance is not sufficient [1417]. To achieve 25(OH)D level of $30 \mathrm{ng} / \mathrm{ml}$, vitamin $\mathrm{D}$ supplementation dose needs to be increased to 1,000 $4,000 \mathrm{IU} /$ day $[14,19,20]$. Individuals with abundant sunlight exposure can easily exhibit a serum $25(\mathrm{OH}) \mathrm{D}$ $>60 \mathrm{ng} / \mathrm{ml}$ which would be a physiologic supplement input of vitamin D intake $>100 \mu \mathrm{g}(4,000 \mathrm{IU} /$ day $)$. Concerns about safety of vitamin D when used in "higher" doses have been largely dispelled with recent evidence that a prolonged intake of even $250 \mu \mathrm{g}(10,000 \mathrm{IU} /$ day $)$ of vitamin $\mathrm{D}_{3}$ is likely to pose no risk of adverse effects [18].

This study evaluates the response to different monthly doses of vitamin D. The study was carried out in New Delhi (location $-28.38^{\circ} \mathrm{N}, 77.12^{\circ} \mathrm{E}$ ). This city experiences marked seasonal variations: spring-February to March, summerApril to June, and winter-November to January. The zenith angle is $84.5^{\circ}$ in peak summer and $38.5^{\circ}$ in peak winter.

Our results showed that $60,000 \mathrm{IU} /$ month $(2,000 \mathrm{IU} /$ day $)$ of cholecalciferol supplementation administered orally for 3 months during summer increased 25(OH)D levels dramatically to near normal levels in group B $(4.8 \pm 3.5$ to $31.6 \pm 15.5 \mathrm{ng} / \mathrm{ml})$. A similar increase $(5.4 \pm 3.0$ to $33 \pm$ $20.7 \mathrm{ng} / \mathrm{ml}$ ) was demonstrated in an Indian study by Goswami et al. [24]. However, the supplementation dose used in their study was higher, $1,500 \mu \mathrm{g}(60,000 \mathrm{IU})$ of cholecalciferol per week $(8,000 \mathrm{IU} /$ day). This supplementation was given for a period of 2 months and evaluation was done during winter months. Their study further showed that these 25(OH)D levels again declined to suboptimal levels, 1 year after discontinuation of vitamin D supplementation. In another study by Veith et al. [22], 25(OH)D levels increased effectively to high-normal concentrations in practically all adults, and serum $25(\mathrm{OH}) \mathrm{D}$ levels remained within the physiologic range following supplementation with $100 \mu \mathrm{g}$ (4,000 IU/day) of cholecalciferol for 6 months.

The study subjects in group A, who did not receive any supplementation, also showed increase in $25(\mathrm{OH}) \mathrm{D}$ levels $(4.5 \pm 3.4$ to $10.8 \pm 7.2 \mathrm{ng} / \mathrm{ml})$ at 3 months. This was most likely due to the effect of seasonal variation on $25(\mathrm{OH}) \mathrm{D}$ levels since the initial samples were drawn in March (spring), and the 3-month samples were drawn in June (summer; zenith angle is $84.5^{\circ}$ in peak summer). Sunlight exposure during summer is more effective in raising 25 (OH)D levels [23]. This was also evident in an earlier study from India which showed higher $25(\mathrm{OH}) \mathrm{D}$ concentrations in summer $(7.1 \mathrm{ng} / \mathrm{ml})$ than in winters $(3.1 \mathrm{ng} / \mathrm{ml})$ [21]. However, the effect of supplementation in group B was more marked as compared to the effect of season in both groups $(P<0.05$; Table 2$)$. 
Table 2 Biochemical measurements in groups A and B after vitamin D supplementation

\begin{tabular}{lccc}
\hline & Group A & Group B & $P$ value \\
\hline 3 months (June) & & & \\
25(OH)D (ng/ml) & $10.8 \pm 7.2$ & $31.6 \pm 15.5$ & $<0.001$ \\
PTH (pg/ml) & $43 \pm 22$ & $38 \pm 16$ & 0.356 \\
Serum calcium (mg/dl) & $9.01 \pm 0.64$ & $9.14 \pm 0.38$ & 0.38 \\
9 months (December) & & & \\
25(OH)D (ng/ml) & $22.4 \pm 12.4$ & $30.7 \pm 12.8$ & $<0.001$ \\
PTH (pg/ml) & $21 \pm 9$ & $19 \pm 8$ & 0.480 \\
Serum calcium (mg/dl) & $9.46 \pm 0.40$ & $9.50 \pm 0.35$ & 0.375 \\
\hline
\end{tabular}

Interesting biochemical responses were seen after 6 months of cholecalciferol supplementation with $60,000 \mathrm{IU} /$ month (group A) vs. 120,000 IU/month (group B). In low-dose group A, 25(OH)D levels increased from $10.8 \pm 7.2$ to $22.4 \pm 12.4 \mathrm{ng} / \mathrm{ml}(P<0.001)$ during the winter months. This increase was less as compared to that achieved in group B with the same dose for 3 months during the summer $(4.8 \pm 3.5$ to $31.6 \pm 15.5 \mathrm{ng} / \mathrm{ml}$; Fig. $2 \mathrm{a})$. This finding emphasizes the winter effect on the $25(\mathrm{OH}) \mathrm{D}$ levels. Serum $25(\mathrm{OH}) \mathrm{D}$ levels have been shown to fall to undetectable levels in Asian Indians during winters in previous studies [21]. During winter, sunlight is less effective in raising the $25(\mathrm{OH}) \mathrm{D}$ levels and levels tend to decline.

A similar effect of season on response to vitamin D supplementation was seen in group B as well. The initial increase in $25(\mathrm{OH}) \mathrm{D}$ levels observed at 3 months (summer) with vitamin D supplementation of $60,000 \mathrm{IU} / \mathrm{month}[4.8 \pm$ $3.5 \mathrm{ng} / \mathrm{ml}$ (March) to $31.6 \pm 15.5 \mathrm{ng} / \mathrm{ml}$ (June)] did not continue at 9 months (winter) $[30.7 \pm 12.8 \mathrm{ng} / \mathrm{ml}]$, despite an increase in the dose to $120,000 \mathrm{IU} / \mathrm{month}$. However, there was no decline and the initial 25(OH)D levels achieved were maintained. Figure $2 \mathrm{a}$ shows this plateau in $25(\mathrm{OH}) \mathrm{D}$ levels. Thus, a drop in $25(\mathrm{OH}) \mathrm{D}$ levels during winter in group B was prevented but at a dose which was double of that used during summer. Therefore, our study confirms the need for higher doses of vitamin D supplementation during winter.

Our study also reconfirms the finding that the average increment in serum $25(\mathrm{OH}) \mathrm{D}$ levels is inversely proportional to the baseline $25(\mathrm{OH}) \mathrm{D}$ levels [19]. The same dose of $50 \mu \mathrm{g}$ /day produced different increments in groups A and $\mathrm{B}$. The average increment produced in group B $(0.5 \mathrm{ng} /$ $\mathrm{ml}$ for every microgram of cholecalciferol administered orally) at 3 months was similar to that reported earlier [13, $19,25]$. However, the increment in group A $(0.2 \mathrm{ng} / \mathrm{ml} / \mu \mathrm{g})$ at 9 months was less with the same dose. In addition to the winter effect, this can be attributed to the higher baseline 25 $(\mathrm{OH}) \mathrm{D}$ level in group A [13].
The increment in $25(\mathrm{OH}) \mathrm{D}$ levels although less was seen in group A with 60,000 IU/month but was not seen at all in group B with $120,000 \mathrm{IU} /$ month during winter months. Again, this can be explained on the basis of the differences in the baseline $25(\mathrm{OH}) \mathrm{D}$ levels in the two groups at 3 months. It has been reported that the average increment in $25(\mathrm{OH}) \mathrm{D}$ levels is $0.3 \mathrm{ng} / \mathrm{ml}$ or less if the baseline $25(\mathrm{OH}) \mathrm{D}$ level is $>28 \mathrm{ng} / \mathrm{ml}$ [19]. The baseline $25(\mathrm{OH}) \mathrm{D}$ level in group B at 3 months was $31.6 \mathrm{ng} / \mathrm{ml}$, which explains for no increment response observed in this group. In group A, the baseline $25(\mathrm{OH}) \mathrm{D}$ level at 3 months was $10.8 \mathrm{ng} / \mathrm{ml}$, much less than the optimal levels. This is clearly demonstrated in Fig. 2a. Other studies have also implied that plateau levels of $25(\mathrm{OH}) \mathrm{D}$ can occur within 5 months [20, 26].

Higher levels of $25(\mathrm{OH}) \mathrm{D}$ generally correlate with lower concentration of PTH [26]. The present data confirm that both doses of supplementation produced a significant suppression of PTH, to about half of the baseline levels (Fig. 2b). Lack of statistical significance in PTH between the dose groups could be attributed to relatively small sample sizes in this study (Table 2).

Serum calcium had increased in both groups at 9 months, but the levels remained within the normal range. There was no evidence of hypercalciuria as a result of long-term use of vitamin $\mathrm{D}$ at a relatively high dose of either $60,000 \mathrm{IU} /$ month (2,000 IU/day) or 120,000 IU/month (4,000 IU/day). This dose was similar to that required to achieve optimal 25 $(\mathrm{OH}) \mathrm{D}$ levels in Caucasians [16]. According to Aloia et al., vitamin D dose of $95 \mu \mathrm{g} /$ day $(3,800 \mathrm{IU})$ for those above a $25(\mathrm{OH}) \mathrm{D}$ threshold of $22 \mathrm{ng} / \mathrm{ml}$ and a dose of $125 \mu \mathrm{g} /$ day $(5,000 \mathrm{IU})$ for those below that threshold is required to achieve $25(\mathrm{OH}) \mathrm{D}$ concentration of $>30 \mathrm{ng} / \mathrm{ml}$. Since our study subjects had very low baseline $25(\mathrm{OH}) \mathrm{D}$ levels with very limited sunlight exposure, the use of higher doses was justified.

Our results showed that daily intake of $50 \mu \mathrm{g}$ (2,000 IU) of vitamin D (cholecalciferol) during summers would bring serum $25(\mathrm{OH}) \mathrm{D}$ levels to the vitamin $\mathrm{D}$-sufficient range in most of the subjects at 3 months. This dose is presently considered to be the safe upper limit of vitamin D intake [14]. Our study also showed that in order to maintain optimal vitamin D levels in winters, even higher doses of $100 \mu \mathrm{g}$ (4,000 IU/day) are required. The 50- $\mathrm{g}$ /day dosage was effective at ensuring $25(\mathrm{OH}) \mathrm{D}$ concentrations of $\geq 20 \mathrm{ng} / \mathrm{ml}$ in $70 \%$ subjects during summer. The $100-\mu \mathrm{g} /$ day dosage was effective at ensuring $25(\mathrm{OH}) \mathrm{D}$ concentrations of $\geq 20 \mathrm{ng} / \mathrm{ml}$ in $81.8 \%$ of the same subjects during winter, similar to that reported by Veith et al. [22]. Our results are similar to those of other studies showing higher $25(\mathrm{OH}) \mathrm{D}$ levels with 4,000 IU of oral vitamin D per day with no risk of hypercalcemia or hypercalciuria [20, 22, 27]. 


\section{Conclusion}

Our study confirms the high prevalence of hypovitaminosis $\mathrm{D}$ in apparently healthy Indian women and shows that in a tropical country like India, monthly oral administration of $60,000 \mathrm{IU}$ cholecalciferol ( 2,000 IU/day or $50 \mu \mathrm{g} /$ day $)$ is effective in raising serum $25(\mathrm{OH}) \mathrm{D}$ to desired levels $(>30 \mathrm{ng} / \mathrm{ml}$ ) during summer. However, higher doses of cholecalciferol $-120,000 \mathrm{IU} / \mathrm{month}$ administered orally $(\sim 4,000 \mathrm{IU} /$ day or $100 \mu \mathrm{g} /$ day — may be more appropriate during winter. This may be an effective public health strategy in severely deficient countries like India.

Acknowledgments The authors are extremely thankful to the management of Indraprastha Apollo Hospital, New Delhi and Sanjay Gandhi Post Graduate Institute, Lucknow for arranging the biochemical testing of the study samples. They would also thank Mr. Deepak Shukla who helped in the statistical analysis.

\section{Disclosures None.}

Open Access This article is distributed under the terms of the Creative Commons Attribution Noncommercial License which permits any noncommercial use, distribution, and reproduction in any medium, provided the original author(s) and source are credited.

\section{References}

1. Lips P (2006) Vitamin D physiology. Prog Biophys Mol Biol 92:4-8

2. Holick MF, Garabedian M (2006) Vitamin D. In: Favus JM (ed) Primer on the metabolic bone diseases and disorders of mineral metabolism, 6th edn. ASBMR, Washington, pp 106-114

3. Arya V, Bhambri R, Godbole MM et al (2004) Vitamin D status and its relationship with bone mineral density in healthy Asian Indians. Osteoporos Int 15(1):56-61

4. Sachan A, Gupta R, Das V et al (2005) High prevalence of vitamin $\mathrm{D}$ deficiency among pregnant women and their newborns in northern India. Am J Clin Nutr 81(5):1060-1064

5. Puri S, Marwaha RK, Agarwal N et al (2008) Vitamin D status of apparently healthy schoolgirls from two different socioeconomic strata in Delhi: relation to nutrition and lifestyle. Br J Nutr 99:876-882

6. Harinarayan CV, Ramalakshmi T, Prasad UV et al (2007) High prevalence of low dietary calcium, high phytate consumption, and vitamin D deficiency in healthy south Indians. Am J Clin Nutr 85 (4):1062-1067

7. Harinarayan CV (2005) Prevalence of vitamin D insufficiency in postmenopausal south Indian women. Osteoporos Int 16:397-402

8. Bhambri R, Naik V, Malhotra N et al (2006) Changes in bone mineral density following treatment of osteomalcia. J Clin Densitometry 9(1):120-127
9. Agarwal KS, Mughal MZ, Upadhyay P et al (2002) The impact of atmospheric pollution on vitamin D status of infants and toddlers in Delhi. India Arch Dis Child 87:111-113

10. Bischoff-Ferrari HA, Dietrich T, Orav EJ et al (2004) Positive association between 25-hydroxy vitamin $\mathrm{D}$ levels and bone mineral density: a population-based study of younger and older adults. Am J Med 116:634-639

11. Trivedi DP, Doll R, Khaw KT (2003) Effect of 4-monthly oral vitamin D3 (cholecalciferol) supplementation on fractures and mortality in men and women living in the community: randomized double-blind controlled trial. BMJ 326:469

12. Bischoff Ferrari HA (2007) The 25 hydroxy vitamin D threshold for better health. J Steroid Biochem Mol Biol 103:614-619

13. Heaney R, Davies KM, Chen TC (2003) Human serum 25hydroxycholecalciferol response to extended oral dosing with cholecalciferol. Am J Clin Nutr 77(1):204-210

14. Bouillon R, Norman AW, Pasqualini JR (2007) Thirteenth workshop on vitamin D. J Steroid Biochem Mol Biol 103:201203

15. Holick MF (2007) Vitamin D deficiency. N Eng J Med 357 (3):266-281

16. Aloia JF, Patel M, Di Maano R et al (2008) Vitamin D intake to attain a desired serum 25-hydroxyvitamin D concentration. Am J Clin Nutr 87(6):1952-1958

17. Whiting SJ, Calvo MS (2005) Dietary recommendations for vitamin D: a critical need for functional end points to establish an estimated average requirement. J Nutr 135:304-309

18. Veith R (2007) Vitamin D toxicity, policy, and science. J Bone Miner Res 22(2):V64-V68

19. Hughes BD, Heaney RP, Holick MF (2005) Estimates of optimal vitamin D status. Osteoporos Int 16:713-716

20. Vieth R, Chan PC, Farlane MGD (2001) Efficacy and safety of vitamin D3 intake exceeding the lowest adverse effect level. Am J Clin Nutr 73:288-294

21. Goswami R, Gupta N, Goswami D et al (2000) Prevalence and significance of low 25-hydroxyvitamin D concentrations in healthy subjects in Delhi. Am J Clin Nutr 72:472-475

22. Vieth R, Kimball S, Hu A (2004) Randomized comparison of the effects of the vitamin D3 adequate intake versus $100 \mathrm{mcg}$ (4000 IU) per day on biochemical responses and the wellbeing of patients. Nutr J 3:8

23. Webb AR, Kline 1, Holick MF (1988) Influence of season and latitude on the cutaneous synthesis of vitamin D3. J Clin Endocrinol Metab 67(2):373-378

24. Goswami R, Gupta N, Ray D et al (2008) Pattern of 25-hydroxy vitamin $\mathrm{D}$ response at short (2 month) and long (1 year) interval after 8 weeks of oral supplementation with cholecalciferol in Asian Indians with chronic hypovitaminosis $\mathrm{D}$. Br J Nutr 100:526-529

25. Holick MF, Biancuzzo RM, Chen TC et al (2008) Vitamin D2 is as effective as Vitamin D3 in maintaining circulating concentrations of 25-hydroxyvitamin D. J Clin Endocrinol Metab 93 (3):677-681

26. Veith R (1999) Vitamin D supplementation, 25-hydroxyvitamin D concentrations, and safety. Am J Clin Nutr 69(5):842-856

27. Malabanan A, Veronikis IE, Holick MF (1998) Redefining vitamin D insufficiency. Lancet 351:805-806 